\title{
The saga of a pink bindweed (Calystegia) from Arthog, Merioneth (v.c.48) with additional evidence
}

\author{
E. Ivor S. Rees* \\ Menai Bridge, Anglesey, North Wales \\ *Corresponding author E. Ivor S. Rees, email: ivorerees@hotmail.co.uk \\ This pdf constitutes the Version of Record published on $14^{\text {th }}$ December 2019

\begin{abstract}
For over five decades the identity of a pink-flowered bindweed (Calystegia) with a broadly rounded leaf sinus from the coast of West Wales has been subject to debate. Initially it was thought to have American origins, but it was subsequently treated as $C$. sepium subsp. spectabilis, a taxon thought to have genetic links to the Far East. Additional finds of other plants on western coasts of Britain and Ireland, and their similarities to a North American subspecies of $C$. sepium also having a broadly rounded leaf sinus now supports the original suggestion of inheritance from a trans-Atlantic drifted migrant.
\end{abstract}

In August 1961 R.K. (Dick) Brummitt (1937 - 2013) and P.M. Benoit collected a pink flowered bindweed (Calystegia) from the fence of a house called Bron Fegla, near Arthog, Merionydd (v.c. 48). For over five decades the identity of it has been variously interpreted. This note, with additional evidence, is a late contribution to that saga. My interest was prompted by the chance find in spring 2017 of some bindweeds with unfamiliar leaf sinus shapes on the Isles of Scilly (v.c.1a) (Fig. 1A). In a section of the BSBI Plant Crib (Rich \& Jermy, 1998) Brummitt had pointed out, with appropriate diagrams, how leaf sinus shapes and the arrangement of veins around them were important features for identifying bindweeds. Following up on the Isles of Scilly find led eventually to an herbarium sheet derived from the Arthog plant which showed a similar leaf sinus shape. The sheet is in the Liverpool University Herbarium and an image of it was viewed using Herbaria@home (http://herbariaunited.org/atHome/). The label on the sheet in Brummitt's handwriting shows that at the time in 1961 he simply called it C. sepium (L.) R. Br. subsp. unknown. Two years later, what must have been the same plant, was listed as C. sepium var. americana when Benoit \& Richards (1963) published their contribution to a Merioneth Flora (a combined second edition of three separate parts originally in Nature in Wales). The variety name was shown to have been based on information from Brummitt. Subsequently the name americana was given to one of three North American subspecies of $C$. sepium native to eastern North America after he had examined material in several American herbaria (Brummitt, 1980).

Dick Brummitt was a world expert on the taxonomy of the Convolvulaceae, describing many new taxa of Calystegia. For many years he was also the BSBI 
Referee for the group (see obituary by Chater, 2014). Amongst taxa he described from the European side of the Atlantic were two with pink flowers, C. sepium subsp. roseata Brummitt (Brummitt, 1967) and C. sepium subsp. spectabilis Brummitt (Brummitt, 1971). Three decades later and using DNA evidence Brown et al. (2009) showed that both $C$. sepium subsp. roseata and $C$. sepium subsp. spectabilis were really hybrids between the white $C$. sepium subsp. sepium of western Europe and taxa originating from other continents. In the samples used for DNA analysis the other parent for $C$. sepium subsp. roseata was found to be $C$. sepium subsp. americana (Sims) Brummitt - a subspecies which occurs on the Azores as well as in eastern North America (Brummitt, 1972), but has not yet been confirmed as occurring in the wild in Britain and Ireland. The scattered pattern of distribution of many records of subsp. roseata in remote places on western coasts of Britain and Ireland led Brown et al. (2009) to suggest that at least in some cases the North American parent probably crossed the Atlantic through natural oceanic drift. An experiment mentioned by Nelson (2000) showing C. sepium seeds remaining afloat for one and a half years would support this hypothesis.

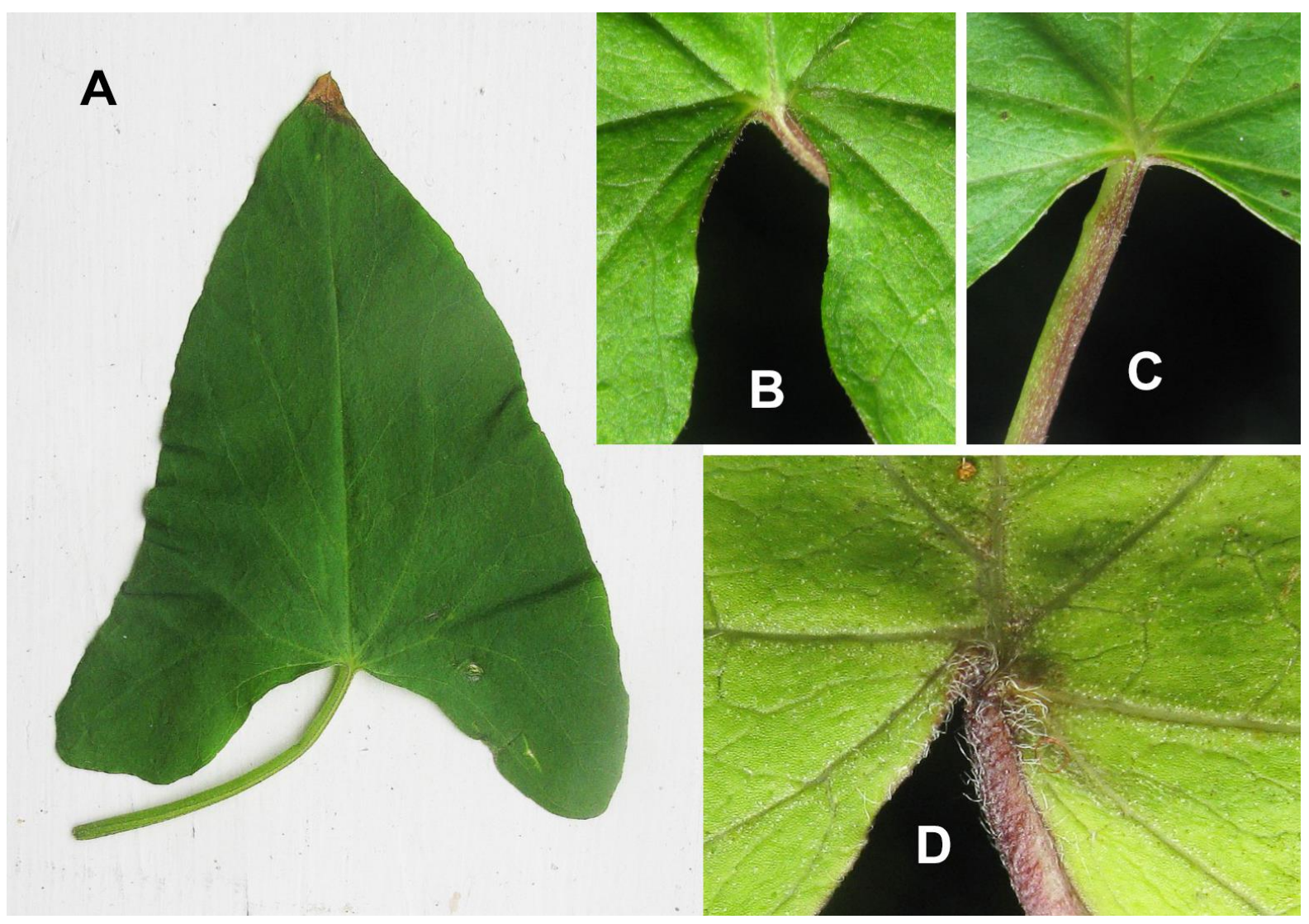

Figure 1. Examples of Calystegia sepium subsp. roseata with differing leaf sinus morphology. (A) Form with very broadly rounded sinus from edge of swamp, St Mary's, Isles of Scilly. (B) Typical narrow sinus form growing at rear of dune ridge, Morfa Abererch, Caernarfonshire. (C) Atypical wide $\mathbf{V}$ sinus form growing amongst boulders just above HWM, Menai Strait, nr Llanfairpwllgwyngyll, Anglesey. (D) Form with longer hairs in leaf sinus than typical growing around the margin of a wetter hollow in coastal heath. Penrhosfeilw, Anglesey. 
In the case of $C$. sepium subsp. spectabilis the type specimens Brummitt chose came from Scandinavia, though even when described in 1971 it was thought to have some connection to the Far East. A notable feature of $C$. sepium subsp. spectabilis is that it has a very broadly rounded leaf sinus. As the 1961 Arthog plant was similar in this respect, the Welsh plant was mentioned when the subspecies was named, but Brummitt himself did not treat it as a type. Ellis (1983) then listed the Arthog plant as having been $C$. sepium subsp. spectabilis, referring to it as an "established alien". Following this the record was repeatedly mentioned as subsp. spectabilis in all four editions of the New Flora of the British Isles (culminating in Stace (2019) and in the New Atlas of the British and Irish Flora (Preston et al, 2002). It should be noted however, that in the section dated December 1997, which Brummitt wrote for the Plant Crib (Rich \& Jermy, 1998) he referred to the Arthog plant in rather less certain terms. He wrote that it "may be the one British plant of $C$. sepium subsp. spectabilis". Also relevant is that when discussing C. sepium subsp. spectabilis in the Flora of China, Rhui-cheng \& Brummitt (1995) wrote that "a similarity to C. sepium subsp. appalachiana Brummitt, from the eastern USA should also be noted". A feature they share is that $C$. sepium subsp. appalachiana also has a leaf sinus that is very broadly rounded (Brummitt, in prep; Spaulding, 2013). Due perhaps to the uncertainty that Brummitt had expressed in print or imparted less formally before he died, the original Arthog record as C. sepium subsp. spectabilis was omitted from the BSBI Database (https://database.bsbi.org/; checked March 2019). There is also no mention of this particular record under any name in the Merionethshire Rare Plant Register (Stille, 2014). C. sepium subsp. spectabilis remained in the database but from a single 1988 inland record on the banks of the river Lea, at Cheshunt, Hertfordshire (v.c.20) (James, 2009).

When the plants with the broadly rounded leaf sinus were first noticed on the Isles of Scilly they were not in flower, but later that summer Rosemary Parslow (Recorder for v.c.1b) was able to confirm that two forms of pink flowered C. sepium subsp. roseata were present in swampy habitats on St Mary's. They were distinguishable on leaf sinus shape and the wide sinus form was the less abundant of the two. Pink flowered plants with similarly broad rounded leaf sinuses have also been found on the coast of Co. Kerry (Paul Green, pers. comm) and one of Brummitt's herbarium specimens also from the west of Ireland labelled as $C$. sepium subsp. roseata has a similar sinus shape.

Searches around the original Arthog site during 1998 by Brummitt and A. Chater as well as independently by P.M. Benoit failed to re-find the plant with the very broadly rounded leaf sinus, so it was considered that it had probably died out locally (Brummitt \& Chater, 2000). They did however record other pink flowered bindweed colonies not far away, particularly in the reedy ditches adjoining Morfa Mawddach Station (formerly Barmouth Junction prior to closure of the line inland through Dolgellau). Reed swamps near Barmouth Junction had been noted by Benoit \& Richards (1963) as a location for C. sepium with pink flowers. Specimens from here were thought by Brummitt \& Chater (2000) to also include a $C$. sepium subsp. roseata $\times$ C. sy/vatica (Kit.) Griseb. hybrid clone. It is of interest that when writing about hybrids in West Wales Brummitt \& Chater (2000) were unwilling to erect new names for some of the apparent combinations they encountered. Some plants I saw in 2017 in the same general locality also had morphological features suggesting they 
could have been of this clone. They lacked the broadly rounded leaf sinus of the 1961 Arthog herbarium specimen but did have a sinus that was a wider V shape than typical of other $C$. sepium subsp. roseata colonies in North Wales. Hybrids involving C. sylvatica (Large Bindweed) or C. pulchra Brummitt \& Heywood (Hairy Bindweed) add further layers of complexity to identification problems but are unlikely to lead to broadly rounded sinus characters. There are suspicions that as a recording category, $C$. sepium subsp. roseata may have been used to encompass more than just the $C$. sepium subsp. sepium $\times$ C. sepium subsp. americana hybrid. Morphological variation can be seen between different $C$. sepium subsp. roseata colonies on the Welsh coast in such features as bracteole and leaf sinus shapes. and sinus hair lengths (Figs. 1B, C \& D).

Although the 1961 Arthog plant had been found growing near a house, the locality is close enough to the seaward end of the Mawddach estuary for ocean drifted debris to sometimes have washed up nearby. This would have been especially so before the Cambrian Coast Railway bridge and associated embankments were built in 1867, and before parts of the adjoining salt marshes were enclosed. Rather than being the site for an unusual non-native bindweed of horticultural origin to establish, the locality is a good candidate for one where a trans-oceanic drifter, or a descendant of one might have got a foothold. The northern arc of Cardigan Bay forms a natural catch basin for drifted debris swept into St George's Channel from the open Atlantic. The BSBI database has a series of localities around the Merioneth and Caernarfonshire parts of the bay with records of C. sepium subsp. roseata.

Bearing in mind the hybrid origin of $C$. sepium subsp. roseata shown by Brown et al (2009), the possibility exists that within the range of variation apparent in plants recorded as subsp. roseata, there might be some that derived from one of the North American taxa other than subsp. americana sensu stricta. The morphological resemblance in the case of the 1961 Arthog plant and a few others at west coast locations now appears to be closer to subsp. appalachiana. Brummitt's initial thoughts expressed to Benoit and Richards in the early 1960s that the Arthog plant had some American ancestry could have been on the right lines after all.

\section{Acknowledgements}

I am most grateful to Rosemary Parslow for confirming with photographs that two forms of $C$. sepium subsp. roseata with differing leaf sinus shapes occur in the Isles of Scilly. Don Spaulding kindly gave me access to the yet unpublished draft which Dick Brummitt had prepared for the Flora of North America. Useful comments on earlier drafts of this paper were made by Ian Bonner and Arthur Chater.

\section{References}

Benoit, P.M. \& Richards, M. 1963. A Contribution to the Flora of Merioneth. $2^{\text {nd }}$ ed. Haverfordwest: West Wales Naturalists Trust. https://bsbi.org/merionethshire

Brown, J.M., Brummitt, R.K., Spencer, M. \& Carine, M.A. 2009. Disentangling the bindweeds: hybridization and taxonomic diversity in British Calystegia (Convolvulaceae). Botanical Journal of the Linnean Society 180: 388-401.

Brummitt, R.K. 1967. Calystegia sepium subsp. roseata Brummitt subsp. nov. Watsonia 6: 298. 
Brummitt, R.K. 1971. Calystegia sepium (L) R. Br. Botanical Journal of the Linnean Society 64: 73.

Brummitt, R.K. 1972. Calystegia. In Flora Europaea, Vol 3, 78-79. Cambridge: Cambridge University Press.

Brummitt, R.K. 1980. Further new names in the genus Calystegia (Convolvulaceae). Kew Bulletin 35: 327-334.

Brummitt, R.K. in prep. Convolvulaceae. For: Flora of North America Editorial Committee eds 1993+. Flora of North America North of Mexico, 20+ Vols. New York and Oxford, Vol. 14.

Brummitt, R.K. \& Chater, A.O. 2000. Calystegia (Convolvulaceae) hybrids in West Wales. Watsonia 23: 161-165.

Chater, A.O. 2014. Richard Kenneth Brummitt (1937-2013). BSBI Yearbook 2014: 90-92.

Ellis, R.G. 1983. Flowering Plants of Wales. Cardiff: National Museum of Wales. James, T.J. 2009. Flora of Hertfordshire. St Albans: Hertfordshire Natural History Society.

Nelson, E.C. 2000. Sea Beans and Nickar Nuts. BSBI Handbook 10. London: Botanical Society of the British Isles.

Preston, C.D., Pearman, D.A. \& Dines, T.D. 2002. New Atlas of the British \& Irish Flora. Oxford: Oxford University Press.

Rich, T.C.G. \& Jermy, A.C. 1998. Plant Crib 1998. London: Botanical Society of the British Isles.

Rhui-cheng, F. \& Brummitt, R.K. 1995. Calystegia. Flora of China. 16, 286-289. http://www.efloras.org/florataxon.aspx?flora id=2\&taxon id=105355

Spaulding, D.D. 2013. Key to the bindweeds (Calystegia and Convolvulus, Convolvulaceae) of Alabama and adjacent States. Phytoneuron 2013-18, 1-12

Stace, C.A. 2019. New Flora of the British Is/es. $4^{\text {th }}$ ed. Suffolk: C \& M Floristics.

Stille, S. 2014. Merionethshire Rare Plant Register. Botanical Society of the British Isles. https://bsbi.org/merionethshire

Copyright retained by author(s). Published by BSBI under the terms of the Creative Commons Attribution 4.0 International Public License.

ISSN: $2632-4970$

https://doi.org/10.33928/bib.2019.01.342 